\title{
Leki do oczu i ich sporządzanie w świetle dziewiętnastowiecznych podręczników do receptury
}

\section{Opthalmic Preparations and Their Production in Light of $19^{\text {th }}$-Century Handbooks of Prescriptions}

This study aims to analyse $19^{\text {th }}$-century handbooks of prescriptions in terms of ophthalmic drug technology. The following publications were selected: Jan Bogumir Freyer's Formulare czyli nauka o sztuczném przepisywaniu lékarstw (Formulare, or on the Art of Writing Prescriptions) - published in Warsaw in 1816, Fryderyk Kazimierz Skobel's Wykład farmakomorfiki i katagrafologii (Lecture on Pharmacomorphics and Catagraphology) published in Krakow in 1851, and Antoni Kryszka's Receptura czyli nauka pisania recept i przyrządzania podług nich lekarstw (Compounding, or on the Art of Writing Presciptions and Preparation of Medicines on their Basis) - published in Warsaw in 1865. In the nineteenth century, ophthalmic medications could be found in three kinds of forms: a dry collyrium (xerocollyrium), an ointment-like collyrium (myrocollyrium), and a liquid collyrium (hygrocollyrium). Ophthalmic medications in solid (powders) and semi-solid (ointments) forms were to contain very finely powdered medicinal substances. The ointments were also required to be non-irritant. Drugs in liquid form (e.g. decoctions, solutions, drops, mixtures) were recommended to be made in accordance with the principles of preparing a given form of the drug. They could be used for instillation, washing or so-called eyebathing, and as eye compresses.

Keywords: history of pharmacy, $19^{\text {th }}$ century, history of dosage forms, ophthalmic preparations

Słowa kluczowe: historia farmacji, XIX w., historia postaci leku, leki do oczu

Narząd wzroku, biorący udział w odbieraniu fal świetlnych i ich przekształcaniu na wrażenia zmysłowe, spełnia złożone funkcje. Oczy są bardzo wrażliwe na czynniki zewnętrzne 


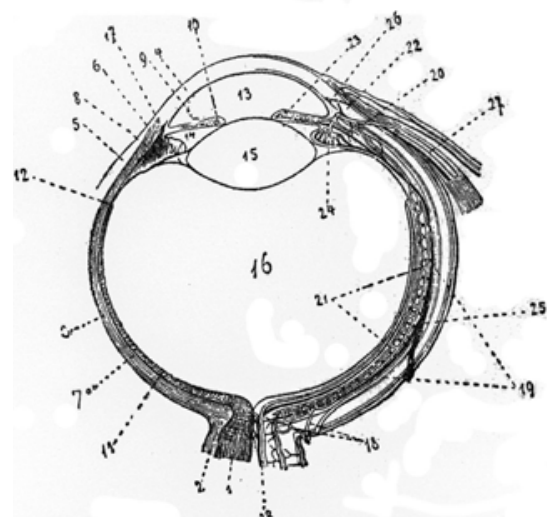

Fig. III. Przekroj poziomy przez galke ocznq. Połowa lewa wsikazuje układ trzech blon gałki, połowa prawa zas uklad naczyń krwionosnych.

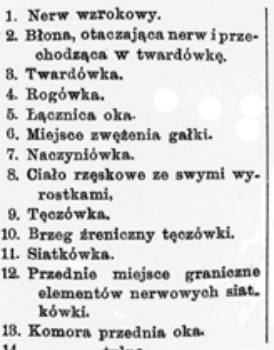
15. Soezewka 16. Cialo szkliste

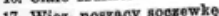
17. Więz, noszapoy soczowken 8. Tylne krotkie tẹtalice xacukoTylne dluzie tętnice rzęskowe. 90. Przednia tọtniea rzęakowa. 21. Siatka wloskowata.

22. Wienieo naezyniowy tęezówki większy.

23. Wieniec nacryniowy tęczówki mniejszy. 94. Naczynia ciała rzęskowego 25. Żsły wirowate.

25. Kanat Schlemma.

27. Gatazki mięsniowe tętnic.

28. Naozynia Grodkowe nerwn

14. Komora przednia okn

Ryc. 1. Schemat budowy oka ludzkiego (Źrócze, Warszawa 1897, s. 7). dło: M. Flaum, Oko ludzkie i organy pomocni-

i narażone na wiele schorzeń. Choroby oczu występują na skutek miejscowych zmian patologicznych o różnych przyczynach, stanów chorobowych innych narządów lub urazów. Choroby oczu można leczyć operacyjnie lub zachowawczo. W tym drugim przypadku używa się substancji leczniczych w odpowiednich formach.

Współcześnie najczęściej do oczu stosuje się takie postacie leku, jak krople do oczu (guttae ophthalmicae), płyny do oczu (collyria) i maści oczne (unguenta ophthalmica). Według współczesnych wymagań farmakopealnych preparaty do oczu przeznaczone do podania na gałkę oczną i/lub na spojówkę lub do umieszczenia w worku spojówkowym należą do grupy leków jałowych. Poza jałowością kroplom do oczu stawia się wymagania dotyczące ciśnienia osmotycznego, pH, nieobecności cząstek nierozpuszczalnych, maściom zaś - nieobecności zanieczyszczeń mechanicznych, odpowiedniej wielkości cząstek substancji leczniczych, właściwej konsystencji oraz braku działania drażniącego".

Warto zwrócić uwagę na termin w języku łacińskim collyrium. Henryk Łuczkiewicz (1826-1891) - tłumacz dzieła Celsusa (53 p.n.e.

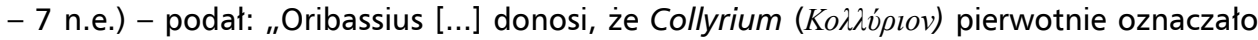
tylko lekarstwo w chorobach ocznych używane (jak i obecnie)"2. Określenie collyrium wyjaśniono też w następujący sposób: „W sztuce lekarskiej okrągła kulka, kuleczka, czopek, języczek [...]. Balsamiczna kulka do oka [...]. Balsam, w ogólności maść na oczy"3. Odnośnie do ostatniej definicji - podobne stwierdzenie znajduje się w Słowniku łacińsko-polskim do autorów klasycznych: „collyrium, ii, n. (z greck.) pigułka balsamiczna na ból ócz i sam ten balsam"4.

Wytłumaczenie różnego definiowania słowa collyrium znajduje się w podręczniku dotyczącym chorób narządu wzroku autorstwa Wiktora Feliksa Szokalskiego (1811-1891), profesora Szkoły Głównej Warszawskiej i lekarza naczelnego Instytutu Oftalmicznego w Warszawie. Czytamy tam:

1 Farmakopea Polska XI, t. 1, Warszawa 2017, s. 1060-1062.

2 Dalej znajduje się wyjaśnienie: „późniéj nazywano tém mianem różne leki w postaci czopków zarabiane, jakoż były: Coll. fistulosa [...]; Coll. alvina = nasze Suppositorium; Coll. urethralis wprowadzane do cewki moczowéj [...]; C. uterina, maciczne" (A. Cornelius Celsus, O lecznictwie ksiąg ośmioro, tłum. H. Łuczkiewicz, Warszawa 1889 , s. 364-365). Collyrium fistulosa miało kształt stożka i używane były do wkładania w przetoki.

3 F. Bobrowski, Lexicon Latino-Polonicum, t. 1, A-K, Wilno 1841, s. 400.

4 Z. Węclewski, Słownik łacinsko-polski do autorow klassycznych, Poznań 1851, s. 71. 
głównie do leczenia w owych czasach [starożytności - E.R.] używano maści twardych (collyria) które rozmiękczano w palcach, lub rozpuszczano w białku albo oleju z tykowego nasienia, potém wcierano w czoło i skronie lub za pomocą pendzli ze skubanki5 (penicella), wprowadzano do oka. Przymoczki czyli dzisiejsze nasze collyria, zwały się wówczas sacta, mniéj nierównie były używane. Collyria miękkie (pixyna) przechowywano w pudełkach drewnianych lub szklannych, twarde zaś formowano w laseczki ${ }^{6}$.

Celem niniejszej pracy jest analiza dziewiętnastowiecznych podręczników do receptury w zakresach rodzajów postaci leków do oczu, charakterystyki tych leków oraz sposobów ich sporządzania, opakowań i metod aplikowania. Podjęta tematyka wpisuje się w tok badań dotyczących historii postaci leku i technologii farmaceutycznej?

Podstawę do opracowania stanowiły następujące publikacje: Formulare czyli nauka o sztuczném przepisywaniu lékarstw (Warszawa 1816) ${ }^{8}$ autorstwa prof. Jana Bogumira Freyera (1778-1828), wykładowcy materii medycznej na Wydziale Akademicko-Warszawskim Nauk Lekarskich, a w późniejszym czasie także patologii szczegółowej i formulare, czyli receptury9; Wykład farmakomorfiki i katagrafologii (Kraków 1851) autorstwa prof. Fryderyka Kazimierza Skobla (1806-1876), wykładowcy patologii, terapii ogólnej oraz farmakognozji na Uniwersytecie Jagiellońskim ${ }^{10}$; oraz Receptura czyli nauka pisania recept i przyrządzania podług nich lekarstw (Warszawa 1865), opracowana przez prof. Antoniego Kryszkę (1818-1912), wykładowcę fizjologii, a następnie farmakologii i terapii ogólnej, materii medycznej i receptury w Cesarsko-Królewskiej Akademii Medyko-Chirurgicznej w Warszawie, a później w Szkole Głównej Warszawskiej ${ }^{11}$. W wymienionych podręcznikach znajdują się zagadnienia odnoszące się zarówno do kwestii prawidłowego przepisywania leków, jak i ich sporządzania.

W XIX w. leki do oczu ze względu na konsystencję dzielono na stałe, półstałe i płynne (używano wówczas zazwyczaj określeń: suche, maziste i wodniste) ${ }^{12}$. Terminologia uży-

5 „Skubanka czyli szarpia składa się z mniejszych lub większych nitek, które się targają ze starego płótna, poprzednio wypranego $z$ ługiem i dobrze wypłukanego w wodzie. Ku temu celowi tnie się płótno na kawałki kwadratowe, równej wielkości (najlepiéj kiedy bok jeden wynosi 2-4 cali), aby pojedyńcze nitki nie były za nadto różne co do długości" (S. Jerzykowski, Przewodnik dla felczerów, sióstr miłosierdzia i w ogóle dla osób zajmujących się pielęgnowaniem chorych, Warszawa 1877, s. 49). Skubanka mogła mieć różne formy, np.: pęczka, kuli, kłębuszka (poduszeczki).

6 W.F. Szokalski, Wykład chorób przyrządu wzrokowego u człowieka, t. 1, Warszawa 1869, s. XLVII.

7 Zob. np.: E. Rutkowska, Proszki jako postać leku $i$ ich sporządzanie $w$ świetle dziewiętnastowiecznego podręcznika do receptury Antoniego Kryszki, „Kwartalnik Historii Nauki i Techniki” t. 58, 2013, nr 2, s. 169181; eadem, Techniki sporządzania odwarów (decocta), naparów (infusa) i maceracji (macerationes) w świetle podręczników do receptury z XIX wieku i pierwszej połowy XX wieku, "Kwartalnik Historii Nauki i Techniki” t. 60, 2015, nr 1, s. 231-246; eadem, Technologia pigułek w XIX wieku na podstawie podręcznika do receptury Antoniego Kryszki, „Kwartalnik Historii Nauki i Techniki” t. 60, 2015, nr 3, s. 103-117; eadem, Maści jako postać leku i ich sporządzanie w świetle dziewiętnastowiecznych podręczników do receptury, „Kwartalnik Historii Nauki i Techniki" t. 62, 2017, nr 2, s. 131-142; eadem, Kołaczki (trochisci, pastilli), morsele (morsuli, tabellae) i krążki (rotulae, orbiculi) jako stałe doustne postaci leku w świetle dziewiętnastowiecznych podręczników do receptury, „Kwartalnik Historii Nauki i Techniki” t. 63, 2018, nr 4, s. 123-137.

8 Drugie wdanie tego podręcznika ukazało się w $1829 \mathrm{r}$.

9 Zob. Polski słownik biograficzny, t. 7, Kraków 1958, s. 134-135.

10 Zob. Polski słownik biograficzny, t. 38, Warszawa 1998, s. 203-205.

11 Zob. Polski słownik biograficzny, t. 15, Wrocław 1970, s. 495-496.

12 A. Kryszka, Receptura czyli nauka pisania recept i przyrządzania podług nich lekarstw, Warszawa 1865, s. 143. 
wana odnośnie do leków do oczu w analizowanych podręcznikach została przedstawiona w Tabeli 1.

Tabela. 1. Nazewnictwo postaci leku do oczu w wybranych dziewiętnastowiecznych podręcznikach do receptury.

\begin{tabular}{|c|c|c|c|}
\hline $\begin{array}{l}\text { Autor } \\
\text { Postać } \\
\text { leku }\end{array}$ & $\begin{array}{c}\text { J.B. Freyer } \\
(1816 \text { r.) }\end{array}$ & $\begin{array}{l}\text { F.K. Skobel } \\
(1851 \text { r. })\end{array}$ & $\begin{array}{l}\text { A. Kryszka } \\
(1865 \text { r.) }\end{array}$ \\
\hline $\begin{array}{c}\text { Stała } \\
\text { (sucha) }\end{array}$ & $\begin{array}{l}\text { Proszek do dmuchania } \\
\text { w oczy (Xerocollyrium) }\end{array}$ & $\begin{array}{l}\text { Proszek na oczy, pro- } \\
\text { szek do zasypywania } \\
\text { lub zadmuchiwania } \\
\text { w oczy, zasypka oczna } \\
\text { (Pulvis ocularius vel } \\
\text { ophthalmicus, } \\
\text { Collyrium siccum) }\end{array}$ & $\begin{array}{l}\text { Proszek do oczu } \\
\text { (Pulvis ophthalmi- } \\
\text { cus) } \\
\text { dawniej: } \\
\text { Xerocollyrium }\end{array}$ \\
\hline $\begin{array}{c}\text { Półstała } \\
\text { (tłustoolej- } \\
\text { na, mazista) }\end{array}$ & Maść (Collyrium) & $\begin{array}{l}\text { Maźć oczna (Unguen- } \\
\text { tum ocularum, Balsa- } \\
\text { mum ophthalmicum) }\end{array}$ & $\begin{array}{l}\text { Maść do oczu } \\
\text { (Unguentum) } \\
\text { dawniej: } \\
\text { Myrocollyrium }\end{array}$ \\
\hline $\begin{array}{c}\text { Płynna } \\
\text { (wodnista) }\end{array}$ & $\begin{array}{l}\text { Wywar do kąpania oczu } \\
\text { (Hygrocollyrium) } \\
\text { Rozciek do kąpania oczu } \\
\text { lub do sporządzania tzw. } \\
\text { papki (z bułką) do okładów } \\
\text { (Collyrium) } \\
\text { Krople „w sposobie wody } \\
\text { do oczu” aplikowane kro- } \\
\text { plami (Collyrium) } \\
\text { Mixtura do kąpania oczu } \\
\text { (Collyrium) }\end{array}$ & $\begin{array}{l}\text { Oczanka (Woda na } \\
\text { oczy) (Aqua ocularia, } \\
\text { Aqua ophthalmica) }\end{array}$ & $\begin{array}{l}\text { Roztwór do oczu } \\
\text { (Collyrium) } \\
\text { dawniej: } \\
\text { Hygrocollyrium }\end{array}$ \\
\hline
\end{tabular}

Źródło: J.B. Freyer, op. cit., s. 86, 159, 185, 197, 202, 336; F.K. Skobel, op. cit., s. 365, 366, 371; A. Kryszka, op. cit., s. 51, 92, 143.

W analizowanych podręcznikach przy redagowaniu recept używano skrótów. Do najczęściej stosowanych należały: $R$. lub $R p$. (Recipe - weź), ana lub aa (ana partes aequales - w równych częściach), M. (Misce - zmieszaj), M.f. (Misce, fiat - zmieszaj, zrób), D. (Da, detur, dentur - daj), S. (Signa, signetur - oznacz), D.S. (Da signaturam, da, signa - wydaj z oznaczeniem).

Dawne jednostki masy stosowane do określenia ilości składników leków recepturowych, to: funty, uncje, drachmy, skrupuły i grany ( 1 funt $=12$ uncji, 1 uncja $=8$ drachm, 1 drachma $=3$ skrupuły, a 1 skrupuł = 20 granów).

\section{Leki do oczu w postaci stałej}

Leki do oczu w postaci stałej miały postać proszku. Freyer określał je jako proszki do dmuchania w oczy (xerocollyrium) i scharakteryzował w następujący sposób: „Proszek w tym zamiarze przepisany z wyboru doświadczonych śrzodków złożony, w przypadku 
zaćmienia błony rogowéy oka, używamy według zasad Terapii, który w naysubtelniéyszy obrócony bydź powinien"13. Ogólna ilość proszku do oczu, przepisanego na recepcie, wynosiła zazwyczaj 1/2 uncji (15 gramów) ${ }^{14}$.

Freyer zamieścił następujący przykład leku recepturowego w postaci proszku do stosowania do oczu:

\section{R. Sacchari albi}

Boli albae

Tartari depurati ana Drachm: unam

Finissime pulverata $M: D$ : ad vitrum.

Signa: Do zewnętrznégo użycia ${ }^{16}$. [cukier, sacharoza, cukier trzcinowy] ${ }^{15}$ [glinka biała]

[kwaśny winian potasowy, kamień winny]

W skład proszku do oczu według Skobla mogła wchodzić jedna lub kilka substancji leczniczych. Składniki tej formy leku musiały być dokładnie roztarte - „jak najmieléj utarte lub utłuczone"17 (co wyrażano na recepcie określeniem w języku łacińskim: M. f. pulvis subtilissimus), a w przypadku proszku złożonego z kilku składników również starannie zmieszane. Ilość ogólną proszków do oczu przepisywaną na jedną receptę,Skobel określił na kilka drachm (1 drachma - 3,25 gramów).

Jako przykład leku w postaci proszku stosowanego „przeciwko śluzotokowi oczu, osobliwie przciągłemu"18 Skobel podał:

Rp. Tannini gr. quindecim, [tanina, kwas taninowy]

Sacchari albi drachmam. [cukier, sacharoza, cukier trzcinowy]

M. f. pulvis subtilissimus.

S. Zasypka oczna ${ }^{19}$.

Innym przykładem proszku do oczu w podręczniku Skobla jest następujący zapis:

Rp. Aluminis usti,

Sacchari albi, utriusque drachmam. [cukier, sacharoza, cukier trzcinowy]

M. f. pulvis subtilissimus.

S. Proszek oczny ${ }^{20}$

Również Kryszka zaznaczył, że proszek do oczu (pulvis ophthalmicus) „przepisuje się jak najmielszy"21, używając w recepcie określenia: pulvis subtilissimus. Przykładem tej formy leku, stosowanej przeciw tzw. śluzotokom, w jego podręczniku jest poniższy przepis:

13 J.B. Freyer, Formulare czyli nauka o sztuczném przepisywaniu lekarstw, Warszawa 1816, s. 86.

14 Ibid.

15 Nazwy polskie składników leków recepturowych w większości przypadków podano w niniejszej pracy według Farmakopei Polskiej II, Warszawa 1937.

16 Recepta nr 74, J.B. Freyer, op. cit., s. 87.

17 F.K. Skobel, Wykład farmakomorfiki i katagrafologii, Kraków 1851, s. 365.

18 Ibid., s. 366.

19 Ibid.

20 Ibid.

21 A. Kryszka, op. cit., s. 51. 
Rp. Plumbi acetici subtilissime pulverati Dr. unam. [octan ołowiawy, cukier ołowiany] D. S. do zasypywania powiek ${ }^{22}$.

Proszki do oczu można było umieścić w butelce szklanej (ad vitrum) lub w tzw. papierze wygładzonym (in charta laevigata). Ten ostatni sposób został wskazany w poniższej recepcie.

Rp. Hydrarg. muriat. mit. Src. semis. [chlorek rtęciawy, kalomel]

Sacchari albi Dr. duas.

[cukier, sacharoza, cukier trzcinowy]

M. f. Pulvis subtilissimus $D$. in charta laevigata

S. do zasypywania oczów ${ }^{23}$.

Zastosowane papieru wygładzonego jako bezpośredniego opakowania dla proszków do oczu było dogodne ze względu na nieprzyleganie cząstek leku do tego materiału.

Proszki do oczu należały w opinii Skobla do rzadko przepisywanej przez lekarzy postaci leku24.

\section{Sposoby aplikowania leków do oczu w postaci stałej}

Autorzy podręczników do receptury zamieścili także informacje na temat używania proszków do oczu. Podczas podawania osobie chorej proszek mógł być wdmuchiwany przez trzonek (dutkę) pióra gęsiego lub strzepywany do oczu za pomocą pędzelka ${ }^{25}$.

Freyer odnośnie do aplikacji leku w formie proszku zamieścił wskazanie: „ustnie chorému lub iégo chirurgowi, opowiadá się sposób używana, iż w jlości granu, náywięcéy dwa razy dniém, sposobém piórka, na miéysce ciérpienia má bydź dmuchanym"26.

Skobel z kolei zaznaczył, że aplikuje się go zwykle jeden raz dziennie, oraz że

wprowadza się on w oko dwojakim sposobem, t. j. albo wpuszczony w kodłuch ${ }^{27}$, wdmuchuje się w takowe. - alboli téż ociera się o oko kisteczka z miękkich włosów, sucha, lub zwilżona jakim łagodnym olejem mazistym (najcześciéj olejem migdałowym), na któréj obległ ów proszek, gdy ją weń włożono. Gdy się to stało, chory na czas niejaki zamyka oko; częstokroć musi je potém przemyć wodą lub mlekiem² ${ }^{28}$.

Do wprowadzenia proszku do oczu mogła być także użyta chorągiewka pióra: „Obmywszy miałki kalomel w wyskoku, osiadający pyłek wprowadza się w ilości kilku gran pod powieki, kosmatym końcem pióra"29.

22 Recepta $\mathrm{nr} 21$, ibid.

23 Recepta nr 20, ibid.

24 F.K. Skobel, op. cit., s. 366.

25 A. Kryszka, op. cit., s. 51.

26 J.B. Freyer, op. cit., s. 86-87. Masa 1 granu wynosiła 0,06 g.

27 Kodłuch - „trzonek pióra (gęsiego)” (zob. A. Brückner, Słownik etymologiczny języka polskiego, Kraków 1927, s. 243).

28 F.K. Skobel, op. cit., s. 366.

29 J. Majer, Obraz postępu nauki lekarskiéj o ile nań wpłynęły prace lekarzy polskich w trzech latach ostatnich, „Rocznik Wydziału Lekarskiego w Uniwersytecie Jagiellońskim” t. 6, 1843, s. 318. 
Do półstałych postaci leków do oczu należały maści. Freyer nie opisywał odrębnie maści do oczu, ale wśród przykładów recept na maści na skórę i błony śluzowe zamieścił w swojej książce również przykład maści przeznaczonej do wcierania w powieki:

R. Butyri recentis loti Dr: duas
Hydrargyri oxydati rubri Gr: sex
Zinci oxydati Gr: duodecim
Camphorae rasae Gr: duo
M: exacte F: Collyrium,
D: ad fictile porcellaneum.

[masło świeże przemyte]

[czerwony tlenek rtęciowy]

[tlenek cynkowy]

[kamfora]

Signa: W jlości soczewicy z rana i wieczorém w powieki wciérać30.

Maści do oczu Skobel opisał jako „leki połączone z jakim tłuszczem, które mają być wprowadzane w oko (t. j. na brzegi i wewnętrzną stronę powiek, tudzież na powierzchnię gałki ocznéj)"31. Podłożami stosowanymi do maści do oczu mogły być tłuszcz wieprzowy (smalec wieprzowy), tłuszcz wieprzowy połączony z woskiem, olej migdałowy z woskiem lub olbrotem. Opisywaną postać leku zalecano sporządzać zazwyczaj w ilości 2 drachm (7,5 gramów).

Przepisując lek w postaci maści, należało podać na początku substancję leczniczą, a następnie podłoże (substancję leczniczą określał Skobel jako „przyjątek”, natomiast podłoże jako „objątek”) oraz zaznaczyć, że lek należy wykonać dokładnie według zasad sztuki (l. a. exactissime $m$. $f$. unguentum ophthalmicum - lege artis exactissime misce fiat unguentum ophthalmicum).

Wykonując maść oczną, substancje lecznicze w postaci stałej należało starannie rozetrzeć. Substancje rozpuszczalne w wodzie Skobel zalecał w niej rozpuścić, nierozpuszczalne - przynajmniej rozetrzeć z małą ilością wody lub oleju.

Rp. Hydrargyri amidato-bichlorati gr. quinque-quindecim, [amidochlorek rtęciowy, chlorek rtęciowoamonowy, chlorek aminortęciwy] Adipis suilli drach. duas.

[smalec wieprzowy]

M. exactiss.

D. in olla alba.

S. Codzień albo co drugi dzień rano, pomazywać powieki od zewnątrz lub wcale od wewnątrz, wziąwszy téj maźci na objętość ziarnka pieprzu².

Maść oczna o podanym powyżej składzie była zalecana we wszystkich schorzeniach oczu, w których występował śluzotok lub ropienie.

Kryszka, podobnie jak Freyer, nie opisał odrębnie maści do oczu, tylko zamieścił jej przykład wśród innych przepisów na maści: 
Rp. Hydrarg praecip. rubri Gr. quinque.

Glyceroli amyli Dr. duas.

M.f. Unguentum

D. S. do oczów ${ }^{33}$. [czerwony tlenek rtęciowy]

[maść glicerynowa]

Na uwagą zasługuje podane w powyższej recepcie podłoże - maść glicerynowa (dawniej: maść glicerolowa), którą wprowadzono do użytku w 1858 r. $^{34}$ Należy ona do podłoży rozpuszczalnych w wodzie.

Na temat maści glicerynowej Kryszka napisał

W ostatnich czasach za excipiens do maści Simon proponował męszaninę Glycerolum amyli, jako dogodniejszą, bo lepiéj pozwalającą się wcierać w wilgocią pokryte części ciała. Do składu téj maści, bierze się glyceryny części 8, krochmalu35 część 1 i dopóty ciągle mieszając nagrzewa, aż utworzy się przezroczysty galaretowaty gąszcz ${ }^{36}$.

Odnośnie do doboru substancji leczniczych podał następującą informację: „Do gąszczu czyli maści glyceryno-krochmalowéj bierzemy środki, w jéj klejowatości bez opadania zawieszające się i same przez się nieoddzielające się"37.

Maści do oczu zazwyczaj umieszczano w słoikach porcelanowych (in olla alba).

\section{Sposoby aplikowania leków do oczu w postaci półstałej}

Najwięcej informacji odnośnie do sposobu używania maści do oczu podał Skobel. Według niego odpowiednią ilością maści umieszczonej na palcu „pomazywano” brzegi zamkniętych powiek albo umieszczano ją na tzw. cienkiej kisteczce z włosów i pocierano wewnętrzną stronę odchylonej powieki dolnej. Następnie chory musiał zamknąć oko i rozprowadzić maść na powierzchni gałki ocznej, np. przez delikatne masowanie powieki. Za dogodne uważano przyjęcie przez chorego pozycji leżącej i stosowanie maści przed snem. Jeżeli zachodziła potrzeba oczyszczenia oczu z maści, używano „letniego mleka lub jakiego innego płynu łagodnego"38.

Rp. Opii crudi gr. sex-decem.

Cum pauxillo

Aquae commun. in pultem tritis admisce

Adipis suilli drach. duas.

M.f. unguentum.

S. Wieczorem, zabrawszy cokolwiek na kisteczkę lub na palec pomazać nią brzegi powiek (albo wprowadzić w samo oko). ${ }^{39}$
33 Recepta nr 79, A. Kryszka, op. cit., s. 92.

34 F. Modrzejewski, Farmacja stosowana, wyd. 1, Warszawa 1957, s. 317.

35 Krochmal to synonim skrobi (Amylum) (zob. L. Rządkowski, Encyklopedja farmaceutyczna, t. 2, Poznań 1936, s. 56-58). Do maści glicerolowej używano zazwyczaj skrobi pszenicznej (Amylum Tritici).

36 A. Kryszka, op. cit. s. 88-89.

37 lbid., s. 90.

38 F.K. Skobel, op. cit., s. 368.

39 Ibid., s. 369. 
Maści do oczu mogły być aplikowane „na objętość ziarna jęczmienia, soczewicy, grochu" $^{\prime 40}$. Na przykład w podanej przez Freyera recepcie zalecano ilość maści porównywalną do wielkości nasienia soczewicy wcierać w powieki ${ }^{41}$.

\section{Leki do oczu w postaci płynnej}

Informacje na temat płynnych leków do oczu w podręczniku Freyera zostały zamieszczone w kilku miejscach. Przykłady recept można znaleźć w częściach poświęconych takim postaciom leku, jak: wywary, rozcieki (tzn. roztwory) i mikstury oraz krople. Trzy pierwsze były przeznaczone do tzw. kąpania oczu lub do sporządzenia okładów i należało je wykonywać zgodnie z zasadami wskazanymi dla danej formy leku.

Przykładem wywaru do tzw. kąpania oczu (hygrocollyrium) był następujący zapis ${ }^{42}$ :

$\begin{array}{ll}R \text {. Herbae Malvae vulgaris Unc: unam } & \text { [ziele ślazu dzikiego] }{ }^{43} \\ \text { coque cum } & \\ \begin{array}{l}\text { Aquae fontanae Unciis sedecim } \\ \text { ad Colaturam Librae unius, cui instilla }\end{array} & \text { [woda studzienna] } \\ \text { Spiritus Vini camphor: gutt: xii } & \text { [spiritus kamforowy] } \\ \text { D: ad vitrum. } & \end{array}$

Signa: Co godzina letnio kąpać oko ${ }^{44}$.

Wśród recept na mikstury (mixtura) Freyer zamieścił jako przykład collyrium:

R. Zinci oxydati Dr: unam

Aquae Rosarum Unc: quinque

M: D. Signa: Do kąpania oczu ${ }^{46}$. [tlenek cynkowy]

[woda różana] ${ }^{45}$

Na temat kropli natomiast Freyer napisał: „Zewnątrz bywá niniéysza forma, rzadko kiedy inaczéy przepisywaná, iak tylko w sposobie wody do oczu (collyrium)" ${ }^{47}$. Jako przykład podał następujący przepis:

40 Ibid., s. 367

41 Recepta nr 304, J.B. Freyer, op. cit., s. 336.

42 Ibid., s. 159.

43 Do sporządzania leków do oczu były głównie stosowane kwiaty i liście ślazu dzikiego (Malva sylvestris L.) pod nazwą herba et flores Malvae vulgaris vel majoris vel silvestris (S. Orgelbrand, Encyklopedyja powszechna, t. 23, Warszawa 1866, s. 576). W lecznictwie używano również Malva neglecta Wallr. i Malva borealis Wallman jako herba et flores Malvae vulgaris vel minoris. Surowiec otrzymywany z Malva sylvestris L. służył „jako środek odmiękczający, obwijający i uśmiérzający drażliwość; i to najwięcéj zewnętrznie w cierpieniach ocznych" (I.R. Czerwiakowski, Botanika lekarska do wykładów, oraz dla użycia lékarzów i aptékarzów, Kraków 1861, s. 292).

44 Recepta nr 174, J.B. Freyer, op. cit., s. 159.

45 Wodę różaną (Aqua Rosarum) można było sporządzić z następującego przepisu: R. Florum Rosarum incarnatarum recentium Libras quatuor, Aquae communis quantum satis. Destillando elice Libras viginti (Pharmacopoeia Regni Poloniae, Varsoviae 1817, s. 97). Z 4 funtów świeżych płatków róży stulistnej (Rosa centifolia L.) przez destylację z parą wodną otrzymywano 20 funtów wody różanej.

46 Recepta nr 249, J.B. Freyer, op. cit., s. 202.

47 Ibid., s. 197. 
R. Liquor: Hydrargyri nitrici Gutt: unam Aquae Laurocerasi Unc: unam Aquae Rosarum Unc: duas $M$ : $D$ : in vitrum.

Signa: 6 razy dniém po kropli w oczy wpusczać ${ }^{48}$.

W składzie innego leku znajdował się kleik z gumy arabskiej:

\section{R. Zinci sulfurici Gr: unum [siarczan cynkowy]} solve in

Aquae Rosarum Unc: una [woda różana] adde

Camphorae, Mucil. Gummi Mimosae subactae Gr: unum

[kamfora, kleik z gumy arabskiej]

D: ad vitrum.

Signa: Co godzina po kropli w oczy wpusczać ${ }^{49}$.

Płynną postać leku do oczu Skobel nazwał oczanką lub wodą na oczy i wyjaśnił, że tymi terminami określano

ciecze lekarskie rzadkie, na to przeznaczone, aby je albo wpuszczać w oko (zakrapiać lub zamuskiwać niemi za pomocą kisteczki) albo takowe niemi okładać lub przemywać (a czasem jeszcze, chociaż to mniéj stósowne, aby w nich oczy kąpać) $)^{50}$.

Leki przepisywano $w$ różnych ilościach: przeznaczone do tzw. zamuskiwania - zazwyczaj 1-2 drachmy (3,75-7,5 gramów), dozowane kroplami - 2 drachmy - 1/2 uncji (7,5-15 gramów), natomiast do przemywań, kąpania oczu lub okładów - kilka uncji (1 uncja - 30 gramów).

Jako rozpuszczalniki w tej formie leku mogły być zastosowane „zwyczajna woda przepędzona, jaki napar lub odwar, albo wreszcie jaka wódka wonna"51. Napary, odwary i wody aromatyczne należało przygotować zgodnie z regułami dotyczącymi sporządzania tych postaci leku.

Skobel podkreślił, że płynne leki do oczu powinny być przesączane, aby nie było w nich elementów mogących drażnić oczy. Nie mogły się znajdować w ich składzie także substancje nierozpuszczone (z wyjątkiem tych, które miały być zastosowane jako okłady na zamknięte powieki).

Jednym z przykładów tzw. oczanki dozowanej kroplami i przeznaczanej do leczenia przewlekłego zapalenia oczu był następujący przepis:

48 Recepta nr 241, ibid., s. 197-198.

49 Recepta nr 242, ibid., s. 198.

50 F.K. Skobel, op. cit., s. 371.

51 lbid. 
Aquae flor. sambuci unciam, [woda z kwiatów bzu czarnego]

Tinct. opii simpl. gutt. viginti. [nalewka opiumowa]

M. S. Do zakrapiania oczu ${ }^{52}$.

Lek, który można było użyć jako płyn do sporządzania okładów, zapisany został następująco:

Rp. Cupri aluminati gr. sex.

[ałun miedziowy, miedź ałunowa, kamień oczny, kamień cudowny, kamień glinowy $]^{53}$

Solve in

Aquae rosar. unc. quatuor.

[woda różana]

Adde

Tinct. opii simpl. gutt. duodecim. [nalewka opiumowa]

M. S. Do okładania oczu ${ }^{54}$.

W podręczniku Kryszki informacje na temat płynnych postaci leku do oczu zostały zamieszczone w części poświęconej Mixturae contractae i opisane następująco:

Jest to więc roztwór, mniéj lub więcéj złożony, mniéj lub więcéj stężony, albo przykładny na powieki, albo pod nie wkraplany. Składa się ze środków przez terapię wskazanych, odpowiednim do ich natury sposobem przyrządzonych, zatém i stosownie przepisanych ${ }^{55}$.

Wśród przykładów recept Kryszka podał przepisy zarówno na tzw. wody do oczu, jak i krople.

Rp. Zinci sulfurici Gr. quatuor.

Aq. destil. Unc. duas.

Tinct. opii croc. Scr. unum.

M. D. S. woda na oczy ${ }^{56}$.

\author{
[siarczan cynkowy] \\ [woda destylowana, woda przekroplona] \\ [nalewka opiumowa szafranowa, nalewka \\ makowcowa szafranowa]
}

W składzie jednego z przykładów wody do oczu znajdował się kleik z nasion pigwy, stosowany w stanach zapalnych narządu wzroku: siarczanu miedziowego i $16 \mathrm{cz}$. drobno sproszkowanego azotanu potasowego, po czym w parownicy porcelanowej topi w umiarkowanej temperaturze (niewiele wyżej $100^{\circ}$ ). Po odstawieniu źródła ciepła dodaje się 1 cz. ałunu j. w. i 1 cz. średnio sproszkowanej kamfory, miesza ogrzaną szpatułką i jednolitą masę wylewa na płytę lub szybko odlewa w laseczki" (zob. L. Rządkowski, Encyklopedja farmaceutyczna, t. 10, Poznań 1939, s. 179).

54 F.K. Skobel, op. cit., s. 375.

55 A. Kryszka, op. cit., s. 144.

56 Recepta nr 144, ibid. 
Rp. Plumbi acetici dep. Gr. sex, Aq. rosarum Unc. tres.

Mucil. cydoniarum Unc. dimidiam.

M. D. S. woda na oczy ${ }^{58}$ [octan ołowiawy, cukier ołowiany] [woda różana]

[kleik z nasion pigwy] $]^{57}$

Krople do oczu, stosowane jako mydriaticum, miały następujący skład:

Rp. Atropini sulfurici Gr. unum.

Aq. destillatae Unc. dimidiam

Solve.

D. S. Do wkraplania w oczy dla rozszerzenia źrenicy ${ }^{59}$. [siarczan atropiny]

[woda destylowana, woda przekroplona]

W powyższym przykładzie stężenie siarczanu atropiny wynosi 0,4\%.

Płynne leki do oczu zalecano umieszczać w tzw. flaszkach, czyli naczyniach szklanych z wąską szyjką i małym otworem (ad vitrum, in vitrum).

\section{Sposoby aplikowania leków do oczu w postaci płynnej}

Płynna postać leku do oczu, przygotowana w małych ilościach, mogła być stosowana przez tzw. zamuskiwanie (pomazywanie) lub dozowana kroplami. Leki o większej masie służyły do przemywania lub tzw. kąpania oczu albo do sporządzania okładów. Ważna była temperatura leku aplikowanego do oczu: „Ciecze przeznaczone do zakrapiania, tudzież do okładów (jeżeli takowe są płynami lekarskiemi) i do przemywania oczu, powinny być używane letnio"60.

Tak zwane zamuskiwanie wymagało użycia specjalnych przyborów - kisteczki z włosów lub włókien azbestowych albo pręcika drewnianego, jak podano w poniższym przykładzie.

\section{Rp. Acor. sulphurici rfti drachmam, [kwas siarkowy oczyszczony] \\ Croci austriaci gr. octo. \\ [znamię szafranu, szafran] ${ }^{61}$}

M.f. massa.

$D$. in vase vitreo bene clauso.

57 Kleik z nasion pigwy można było sporządzić np. z następującego przepisu: Rp. Sem. cydoniorum drachmam, Aquae destill. simpl. Unc. Octo. Nasiona należało wytrawiać wodą destylowaną przez kilka godzin, mieszając od czasu do czasu, po czym przecedzić (F. Skobel, Projekt do Farmakopei dla szpitalów W.M. Krakowa, „Rocznik Wydziału Lekarskiego w Uniwersytecie Jagiellońskim" t. 5, 1842, s. 42). O zastosowaniu w lecznictwie nasion pigwy pospolitej (Cydonia oblonga Mill.) I.R Czerwiakowski napisał: „Lékarskiemi są nasiona Pigw - semina Cydoniarum, raczéj kléj ich zewnętrzny jako kléj nasion pigwowych - mucilago seminum Cydoniarum do dziś dnia przepisywany zewnętrznie w zapaleniach ocznych" (I.R. Czerwiakowski, op. cit., s. 341).

58 Recepta nr 147, A. Kryszka, s. 144.

59 Recepta nr 146, ibid.

60 F.K. Skobel, op. cit., s. 373.

61 Crocus austriacus (Crocus sativus L.) uprawiany na terenach Austrii (okolice Krems i Mölk) należał do najbardziej docenianych, ale także najdroższych odmian (K.D. Ritter von Schroff, Lehrbuch der Pharmacognosie: mit besonderer Berücksichtigung der österreichischen Pharmacopoe vom Jahre 1869, Wien 1869, s. 73-76). Szafran w podanej recepcie służył do zagęszczenia kwasu siarkowego. Zamiast niego można było zastosować inny proszek roślinny. 
S. Umaczawszy w tym gąszczu pręcik drewniany, zwilżyć nim miejsca wskazane (powieki z wierzchu, jeśli te są podwinięte; od wewnątrz zaś, jeżeli na nich w skutek tak zwanego zapalenia egipskiego ponarastały niby brodawki) ${ }^{62}$.

Kolejnym sposobem stosowania płynnego leku do oczu było jego zakraplanie do worka spojówkowego. Lek można było dozować bezpośrednio z opakowania (np. flaszeczki) albo z łyżeczki, do której wlano część płynu, czy też z kodłucha. Odnośnie do ostatniej metody Skobel wyjaśnił:

W tym celu macza się w takim płynie kodłuch odcięty od szypułki, w tém miejscu zatkany palcem, od dołu zaś kończasto zakrojony. Tym sposobem zawsze zawiśnie na nim kilka kropel, które za zbliżeniem pióra do oka, wpadają w nie za odjęciem palca od górnego otworu kodłucha ${ }^{63}$.

Zabieg tzw. kąpania oczu przeprowadzano w specjalnych wanienkach szklanych lub porcelanowych. Jego wykonywanie było zalecane w podręczniku Freyera, natomiast Skobel wspominał o nim jako jeszcze czasem wykonywanym, ale mniej stosownym niż przemywanie lub okładanie.

Z kolei okłady sporządzano np. łącząc lek w postaci płynnej z roztartą bułką do uzyskania tzw. papki, którą wkładano w płótno i stosowano na oczy. Obrazuje to poniższy przykład:

R. Zinci sulphurici Gr: viginti quatuor [siarczan cynkowy] solve in

Aquae destillatae simplicis Libra una [woda destylowana, woda przekroplona] adde

Tinct: Opii crocatae Dr: unam

[nalewka opiumowa szafranowa, nalewka makowcowa szafranowa]

$D$ : in vitrum.

Signa: Do sporządzénia z bułką papki, i przykładánia na noc takowéy do oczu ${ }^{64}$.

W przypadku sporządzania okładów na oczy można było również płynem nasączyć tzw. płatki płócienne (złożone na dwie lub cztery części) lub tzw. zwitki skubankowe. Użycie tych ostatnich uważano za bardziej odpowiednie, a Skobel wyjaśnił to w następujący sposób:

Ponieważ skubanka lepiej przylega do powiek niż płatek przeto wtedy dajemy jej pierwszeństwo, jeżeli nam nie chodzi o rozgrzanie lub ochłodzenie oczu, jak raczej o otrzymanie skutku właściwego lekowi, w tej podobie użytego ${ }^{65}$.

W niektórych przypadkach zalecano aplikowanie płynnych leków do oczu za pomocą strzykawki: „Jeśli powieki nabrzmiały, albo jeżeli chcemy tylko działać na przewody łzowe, 
wtedy do użycia oczanki potrzeba osobnéj strzykawki"66. Wymagano wówczas przygotowania leku w ilości od 1/2 do 2 uncji (15-60 gramów).

\section{Podsumowanie}

Autorzy analizowanych podręczników w różny sposób ujęli zagadnienia leków do oczu. Odrębną część w swojej pracy poświecił im tylko Skobel, a w porównaniu z Freyerm i Kryszką najszerzej opisał on również kwestie rodzajów postaci leków do oczu i metody ich aplikowania. Mogły na to wpłynąć odmienne zainteresowania piszących tematem i rozwój wiedzy.

Wymagania, jakie stawiano w dziewiętnastym wieku lekom do oczu w postaci stałej dotyczyły odpowiedniego stopnia rozdrobnienia substancji leczniczych (miały one być przygotowane jako pulvis subtilissimus, czyli jako proszek bardzo miałko sproszkowany). Przy wykonywaniu maści również należało dokładnie rozetrzeć substancje, rozpuszczalne w wodzie zalecano w niej rozpuścić, natomiast nierozpuszczalne - przynajmniej rozetrzeć z małą ilością wody lub oleju oraz dokładnie wymieszać składniki leków. Przy sporządzaniu płynnych postaci leku zwracano uwagę na ich przesączanie, aby pozbyć się elementów mogących drażnić oczy.

Należy zaznaczyć, że wszystkie analizowane podręczniki wydane zostały przed przełomem bakteriologicznym (zapoczątkowanym badaniami Louisa Pasteura (1822-1895) i Josepha Listera (1827-1912)). Przełom ten przyczynił się do sformułowania zaleceń przyrządzania leków do oczu w sposób aseptyczny oraz wprowadzenia wymagań czystości mikrobiologicznej postaci leku (w tym leków do oczu). Biorąc pod uwagę to, że często występującym schorzeniem narządu wzroku są jego stany zapalne (spowodowane zakażeniem bakteryjnym, wirusowym, grzybiczym, pierwotniakowym), można przypuszczać, że dużym problemem w dziewiętnastym wieku były także zakażenia odlekowe, spowodowane stosowaniem zanieczyszczonych mikrobiologicznie preparatów. Mogły one prowadzić do uszkodzeń narządu wzroku.

Niemniej jednak wśród substancji leczniczych w dziewiętnastowiecznych preparatach do oczu stosowano związki chemiczne o działaniu przeciwbakteryjnym (sole rtęci, ołowiu czy cynku). Nie wymagano również wówczas od płynnych leków do oczu odpowiedniego ciśnienia osmotycznego, ani pH. Roztwory różniące się znacznie ciśnieniem osmotycznym od płynu łzowego mogły wywoływać drażnienie oka (związane z uczuciem pieczenia i łzawienia). Również wprowadzanie do oczu roztworów kwaśnych o pH poniżej 3,5 lub alkalicznych o pH powyżej 10 było szkodliwe dla narządu wzroku.

\section{Bibliografia}

Czerwiakowski I.R., Botanika lekarska do wykładów, oraz dla użycia lékarzów i aptékarzów, Kraków 1861. 
Freyer J.B., Formulare czyli nauka o sztuczném przepisywaniu lekarstw, Warszawa 1816.

Kryszka A., Receptura czyli nauka pisania recept i przyrządzania podług nich lekarstw, Warszawa 1865.

Skobel F.K., Wykład farmakomorfiki i katagrafologii, Kraków 1851.

Szokalski W.F., Wykład chorób przyrządu wzrokowego u człowieka, t. 1, Warszawa 1869.

dr n. farm. Elżbieta Rutkowska pracuje w Zakładzie Farmacji Stosowanej Uniwersytetu Medycznego w Białymstoku. Jej zakres zainteresowań badawczych obejmuje historię farmacji, a szczególnie historię technologii postaci leku, historię leku roślinnego oraz historię aptekarstwa w XIX i XX w.

e-mail: elzbieta.rutkowska@umb.edu.pl

Data zgłoszenia artykułu: 16 października 2019

Data przyjęcia do druku: 3 stycznia 2020 